九州大学学術情報リポジトリ

Kyushu University Institutional Repository

\title{
Source Activity Evaluation by Grafted Leaves in Sweet Potato (Ipomoea batatas Lam.) Cultivars.
}

Ishida, Akiko

Laboratory of Plant Production Physiology, Division of Bioresource and Bioenvironmental

Sciences, Graduate School, Kyushu University

Kubota, Fumitake

Laboratory of Plant Production Physiology, Division of Bioresource and Bioenvironmental Sciences, Graduate School, Kyushu University

Kadowaki, Masayuki

Laboratory of Plant Production Physiology, Division of Bioresource and Bioenvironmental Sciences, Graduate School, Kyushu University

Saitou, Kazuyuki

Laboratory of Plant Production Physiology, Division of Bioresource and Bioenvironmental Sciences, Graduate School, Kyushu University

https://doi.org/10.5109/24308

出版情報: 九州大学大学院農学研究院紀要. 44 (1/2)，pp.73-80，1999-11. Kyushu University バージョン：

権利関係: 
J. Fac. Agr., Kyushu Univ., 44 (1·2), 73-80 (1999)

\title{
Source Activity Evaluation by Grafted Leaves in Sweet Potato (Ipomoea batatas Lam.) Cultivars.
}

\author{
Akiko Ishida, Fumitake Kubota, Masayuki Kadowaki and Kazuyuki Saitou \\ Laboratory of Plant Production Physiology, Division of Bioresource and Bioenvironmental Sciences, \\ Graduate School, Kyushu University, Hakozaki, Higashi-ku, Fukuoka 812-8581, Japan \\ (Received July 22, 1999 and accepted August 24, 1999)
}

\begin{abstract}
The cultivaral feature and difference in leaf source activity were evaluated by using two-leaf grafts (plantlets with two grafted leaves) of sweet potato (Ipomoea batatas Lam.) cultivars. Two cultivars, Koganesengan ([K]) and Tsurunashigenji ([T]), characterized by high and low abilities in leaf photosynthesis, respectively, were used as experimental materials. A plantlet with two $[\mathrm{K}]$ leaves grafted onto the stock of $[\mathrm{T}]$ was described here as $[\mathrm{K}+\mathrm{K}] /[\mathrm{T}]$. Using the grafts with six combinations of $[\mathrm{K}+\mathrm{K}] /[\mathrm{T}],[\mathrm{K}+\mathrm{K}] /[\mathrm{K}],[\mathrm{T}+\mathrm{T}] /[\mathrm{T}],[\mathrm{T}+\mathrm{T}] /[\mathrm{K}],[\mathrm{K}+\mathrm{T}] /[\mathrm{T}]$ and $[\mathrm{K}+\mathrm{T}] /[\mathrm{K}]$, the leaf photosynthetic rate (Pn) and leaf area (LA) were measured and compared between these combinations. Pn and LA in both cultivars increased in the grafts with [K] stock. When compared between lcaves of $[\mathrm{K}]$ and $[\mathrm{T}]$ grafted to the same stock, higher values were obtained in both parameters in [K] leaves. The source activity (SOA; a product of Pn $x$ LA) in $[\mathrm{K}]$ leaves showed two to three times higher than that of [T] leaves. This fact suggests that the cultivaral differences in both Pn and LA are more clearly observed when two leaves are placed under competitive conditions by grafting. The two-leaf graft employed here was proved to be useful as a test plant for evaluating the photosynthetic potential and its cultivaral feature in a single leaf of sweet potato.
\end{abstract}

\section{IN'R'RODUCTION}

The productive function in a plant is divided into two main parts as source and sink. The theory based on sink-source functional balance is frequently applied to analytical studies on biomass production, and until now there have been many reports describing the relative importance or strength between source and sink as a production determinant of crops. In sweet potato plant used here as an experimental material, these two functions are separate from each other as top and root in a plant, and placed in a comparatively simple relationship. The easiness of grafting is also a beneficial point of this species as the experimental material (Hojo and Park, 1971a; Hojo et al., 1971b; Nakatani et al, 1988). In particular, the single-leaf graft (a plantlet with a grafted leaf) is a mostly simplified model in the source-sink relationship, and has been effectively used for studies on source-sink relationships at various levels from dry matter production to biochemical analysis (Nakatani and Komeichi, 1988, 1992; Kubota et al., 1993). In a common result from these reports, the importance of sink activity seems to be overly estimated as a determinant factor of sweet potato yield compared to that of source activity.

Single-leaf grafts with various scion and stock combinations are useful to examine the leaf photosynthetic response of a cultivar in relation to the sink activity. When we want to obtain a more accurate photosynthetic evaluation between different cultivars, the two-leaf graft is regarded as an adequate and useful model, because photosynthetic 
features are expected to appear more definitely under the condition where the two grafted leaves are competitively grown on the same stock. In the present study, we prepared two-leaf grafts with different cultivaral combinations of scion (leaves) and stock (stem and root), and examined the utilization of two-leaf grafts as test plants for evaluating the photosynthetic characteristics in sweet potato cultivars.

\section{MATERIALS AND METHODS}

Two cultivars, Koganesengan ([K]) and Tsurunashigenji ([T]), were used as experimental materials. The former is a recently developed cultivar with a high activity in leaf photosynthesis and sink function, and the latter is a traditional cultivar with a low activity in both.

The grafting was carried out using the technique described by Nakatani et al. (1988). Sweet potato shoots having eight expanded leaves were sampled from these two cultivars grown in an agricultural experimental field of Kyushu University to use them as stocks of the grafts. The 4 th to 8 th leaves including petioles were removed from the shoot stems and their stem nodes were placed under water to promote rooting. Following several days after this treatment, the petioles of the 2nd and 3rd leaves were cut off in the middle to graft two leaves to the cut ends. After the grafted portion was completely adhered, the shoots, of which stem below the 5th node was cut away, were transplanted in sandy soil in a cylinder pot with a capacity of $8.3 \mathrm{~cm}$ diameter and $20 \mathrm{~cm}$ depth. After complete rooting in the soil, the remaining first leaf was removed and the grafts with two leaves were grown for 35 days in a green house. The buds growing from stocks were picked off on the spot when they appeared. As the basal fertilizing, chemical compound including elements $(\mathrm{N}$, $\mathrm{P}$ and $\mathrm{K} ; 16 \%$ each) was applied $5 \mathrm{~g}$ per pot.

The prepared grafts were composed of six combinations of scions (two leaves) and stock (stem + root) as shown in Fig. 1. The plantlet in which two $[\mathrm{K}]$ leaves are grafted to $[\mathrm{K}]$ stock is described here as $[\mathrm{K}+\mathrm{K}] /[\mathrm{K}]$. The combinations of two [T] leaves to $[\mathrm{K}]$ stock, and $[K]$ and $[\mathrm{T}]$ leaves to $[\mathrm{K}]$ stock are $[\mathrm{T}+\mathrm{T}] /[\mathrm{K}]$ and $[\mathrm{K}+\mathrm{T}] /[\mathrm{K}]$, respectively. Similarly these scion leaves grafted to the stock of $[\mathrm{T}]$ are $[\mathrm{K}+\mathrm{K}] /[\mathrm{T}],[\mathrm{T}+\mathrm{T}] /[\mathrm{T}]$ and $[\mathrm{K}+\mathrm{T}] /[\mathrm{T}]$, respectively.

Leaf photosynthetic rate (Pn), stomatal conductance (Gs) and mesophyll conductance $(\mathrm{Gm})$ were measured at the intervals of 7 days during the growth period of 35 days using a portable photosynthesis-evaporation system (SPB-H3, ADC, UK). The intensity of measurement light was 1,700 to $1,800 \mu \mathrm{mol} \mathrm{m}^{-2} \mathrm{~s}^{-1} \mathrm{PAR}$, and the relative humidity and air temperature in the assimilation chamber were about $40 \%$ and $30^{\circ} \mathrm{C}$, respectively.

Three to five grafts in each combination were harvested on the final day of the growth period of 35 days, and the obtained samples were divided into four parts, leaf, leaf petiole, stem and root. The roots were further separated into three parts, fibrous root (less than $2 \mathrm{~mm}$ in diameter), thick root ( 2 to $5 \mathrm{~mm}$ ) and tuberous root (more than $5 \mathrm{~mm}$ ). The area of each leaf (LA) was measured with an automatic area meter (AAA-M8, Hayashi-denkoh, Japan).

Adenosine 5'-diphosphate glucose pyrophosphorylase (AGPase) is an enzyme catalyzing the subfinal step in starch synthetic procedure in amyloplasts of root, and it 

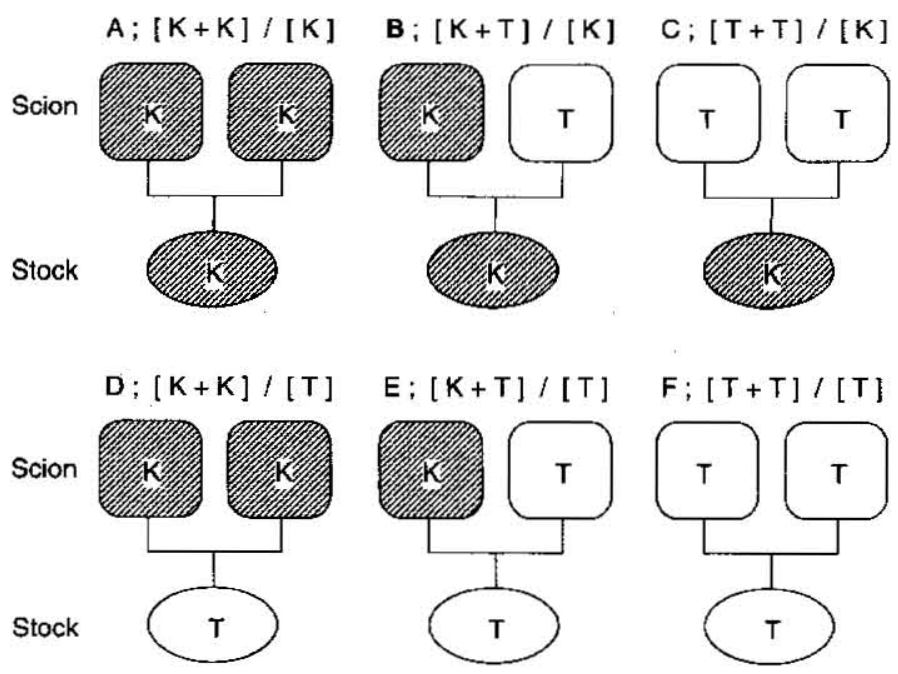

Fig. 1. The grafting combinations of scion (leaf) and stock (stem+ root).

has been known as one of the key enzymes governing the starch synthesis or sink activity (Nakatani and Komeichi, 1992; Tsubone et al. 1997). Directly after some segments were sampled from the thickest part of tuberous root, they were weighed and frozen in liquid nitrogen, then stored at $-80^{\circ} \mathrm{C}$. The stored segments were used for measurement of AGPase activity.

Enzyme extraction was carried out according to the method described by Yatomi et al. (1996). All the procedures were carried out at $0-4^{\circ} \mathrm{C}$. For the assay of AGPase activity, a tissue segment (about $0.5 \mathrm{~g}$ fresh weight) was quickly homogenized with a pestle in an ice-cold mortar that contained $250 \mathrm{mM}$ Tricine-- $\mathrm{NaOH}(\mathrm{pH} 8.0), 20 \mathrm{mM} \mathrm{MgCl}_{2}$, $2 \mathrm{mM} \mathrm{Na}-$ EDTA, $12.5 \%$ (v/v) glycerol, $10 \mathrm{mM}$ dithiothreitol and $10 \%(\mathrm{w} / \mathrm{v})$ polyvinylpyrrolidone at a ratio of a segment to buffer of $1 \mathrm{~g}$ to $10 \mathrm{ml}$. The homogenate obtained was centrifuged at $10,000 \times \mathrm{g}$ for $\overline{\mathrm{min}}$, and the resulting supernatant was used as the preparation for enzyme assay. The activity of AGPase was measured through the procedure described by Nakamura et al. (1989).

\section{RESULTS AND DISCUSSION}

Fig. 2 shows the dry matter weight of each organ and top-root ratio (T/R) in the two-leaf grafts sampled on the 35 th day after transplanting. The root production varied with scion-stock combination; the largest value was obtained in the graft of $[\mathrm{K}+\mathrm{K}] /[\mathrm{K}]$, whereas the smallest one was observed in that of $[\mathrm{T}+\mathrm{T}] /[\mathrm{T}]$. When the root production was compared between both stock cultivars, the grafts with $[\mathrm{K}]$ stock had a larger value than those having $[\mathrm{T}]$ stock. This is regarded as a result from the difference in sink 


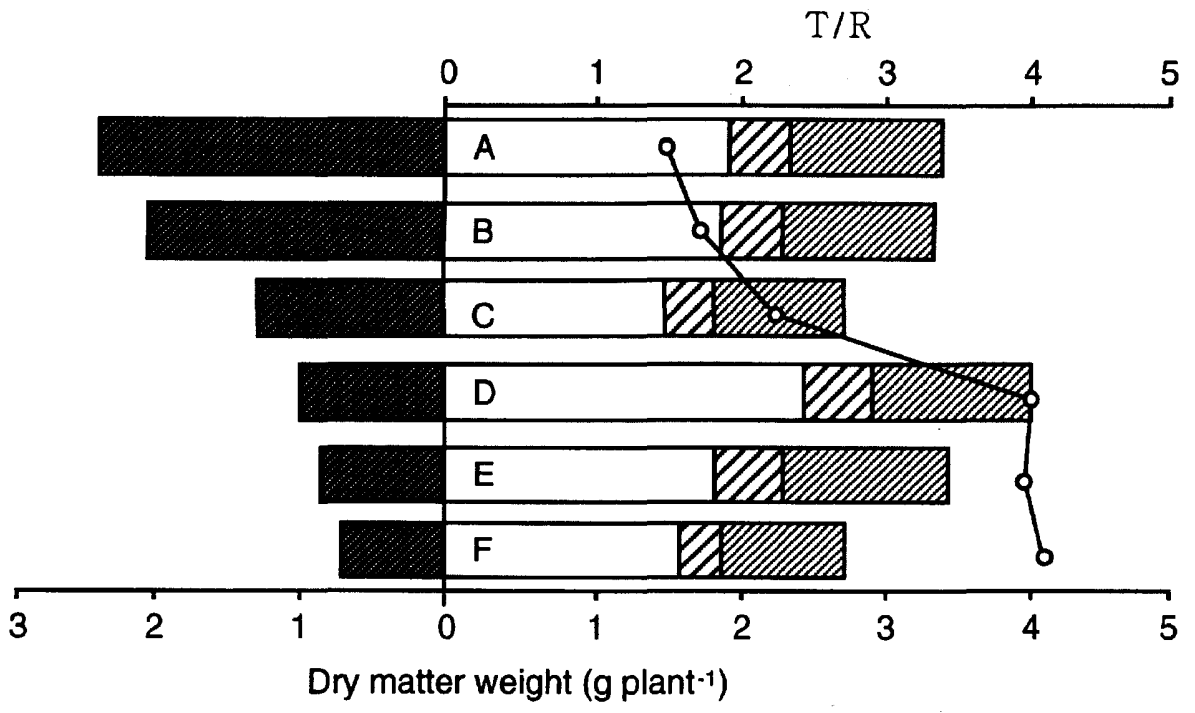

Fig. 2. The partitioning ratios of dry matter weight and $T / R$ ratio in grafts sampled on the 35 th day after transplanting. See Fig. 1 for the letters of A to E.
, Root;
$\square$, stem;
$\boldsymbol{\nabla}$, petiole;
Q, leaf; -O- T/R.

activity between stock cultivars, as already described by Nakatani and Komeichi (1988) and Kubota et al. (1993). So far the source activity of sweet potato has been evaluated less important as a yield determinant, but in our experimental result the scion function is significantly effective on root production, that is, the largest root production was observed in a leaf combination of $[\mathrm{K}+\mathrm{K}]$, then followed by $[\mathrm{K}+\mathrm{T}]$ and $[\mathrm{T}+\mathrm{T}]$ in both grafts with $[\mathrm{K}]$ and $[\mathrm{T}]$ stocks. This may suggest that the root production in sweet potato is not only restricted by sink activity of the stock but also considerably restricted by source activity of the scion, and this may support that the effect of source activity should be evaluated as a more important determinant in sweet potato production.

The weight of aboveground part of plant including stem, petiole and leaf increased in the grafts with $[\mathrm{T}]$ stock, and accordingly T/R became higher in these grafts. It may be considered that a high partitioning ratio of the top part of plant is caused by the restriction of photosynthate transport from leaf to root in the graft having a poor sink cultivar such as [T], and this allows the plant to accumulate more photosynthate in the aboveground part.

The source activity (SOA) consists of quantitative (LA) and qualitative (Pn) factors. In Fig. 3 the effect of stock cultivar on LA expansion is shown. There was not a significant difference in LA between $[\mathrm{K}+\mathrm{K}] /[\mathrm{K}]$ and $[\mathrm{K}+\mathrm{K}] /[\mathrm{T}]$, and also between $[\mathrm{T}+$ $\mathrm{T}] /[\mathrm{K}]$ and $[\mathrm{T}+\mathrm{T}] /[\mathrm{T}]$. However, a large cultivaral difference was observed in LA in the grafts with $[\mathrm{K}+\mathrm{T}]$ leaves. In these grafts the LA of $[\mathrm{K}]$ was significantly larger than the area of a single leaf in the grafts with $[\mathrm{K}+\mathrm{K}]$ leaves. Contrary to this, the LA of $[\mathrm{T}]$ in the grafts with $[K+T]$ leaves decreased. The increased size of $[K]$ leaf is regarded as a 


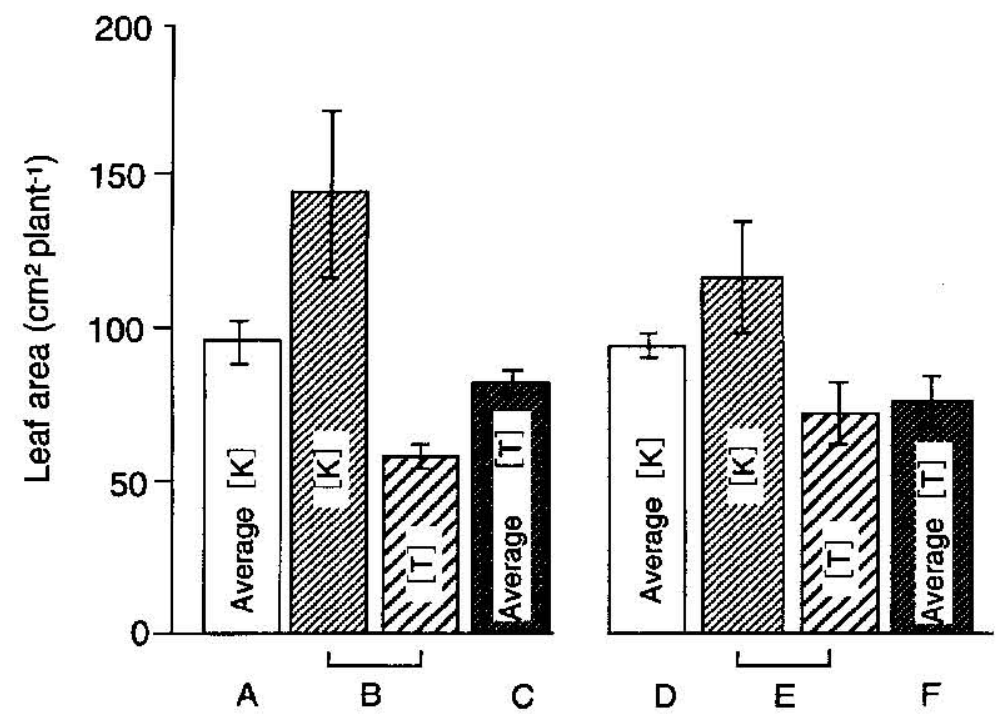

Fig. 3. Leaf areas of grafts with six scion - stock combinations. Leaf area was measured on the 35 th day after transplanting. See Fig. 1 for the letters of $\mathrm{A}$ to $\mathrm{E}$. The vertical bars show standard error.

Table 1. Photosynthetic rate (Pn), stomatal conductance (Gs) and mesophyll conductance $(\mathrm{Gm})$ in the grafts with six scion - stock combinations. Each parameter value is the average obtained during 35 days. See Fig. 1 for the letters of $A$ to $E$.

\begin{tabular}{cccccc} 
Combination & Stock & Scion leaf & Pn $\left(\mu m \mathrm{~m}^{2} \mathrm{~s}^{1}\right)$ & Gs $\left(\mathrm{mol} \mathrm{m}^{2} \mathrm{~s}^{1}\right)$ & Gm $\left(\mu m o l \mathrm{~m}^{2} \mathrm{~s}^{1}\right)$ \\
\hline A & {$[\mathrm{K}]$} & {$[\mathrm{K}]$} & $16.43 \pm 1.15 \mathrm{a}$ & $0.37 \pm 0.01 \mathrm{a}$ & $0.060 \pm 0.005 \mathrm{a}$ \\
$\mathrm{B}$ & {$[\mathrm{K}]$} & {$[\mathrm{K}]$} & $15.43 \pm 1.28 \mathrm{ab}$ & $0.36 \pm 0.02 \mathrm{a}$ & $0.057 \pm 0.065 \mathrm{ab}$ \\
$\mathrm{B}$ & {$[\mathrm{K}]$} & {$[\mathrm{T}]$} & $12.61 \pm 0.67 \mathrm{~b}$ & $0.34 \pm 0.01 \mathrm{a}$ & $0.044 \pm 0.064 \mathrm{~b}$ \\
C & {$[\mathrm{K}]$} & {$[\mathrm{T}]$} & $13.71 \pm 1.01 \mathrm{ab}$ & $0.33 \pm 0.01 \mathrm{a}$ & $0.049 \pm 0.004 \mathrm{ab}$ \\
\hline D & {$[\mathrm{T}]$} & {$[\mathrm{K}]$} & $14.82 \pm 0.88 \mathrm{a}$ & $0.35 \pm 0.01 \mathrm{a}$ & $0.056 \pm 0.005 \mathrm{a}$ \\
E & {$[\mathrm{T}]$} & {$[\mathrm{K}]$} & $14.31 \pm 0.85 \mathrm{ab}$ & $0.33 \pm 0.01 \mathrm{ac}$ & $0.053 \pm 0.004 \mathrm{a}$ \\
E & {$[\mathrm{T}]$} & {$[\mathrm{T}]$} & $11.92 \pm 0.56 \mathrm{~b}$ & $0.28 \pm 0.01 \mathrm{~b}$ & $0.044 \pm 0.003 \mathrm{a}$ \\
F & {$[\mathrm{T}]$} & {$[\mathrm{T}]$} & $13.38 \pm 0.93 \mathrm{ab}$ & $0.31 \pm 0.02 \mathrm{bc}$ & $0.048 \pm 0.005 \mathrm{a}$ \\
\hline
\end{tabular}

Values with different letters in each column are significantly different at 5\% level by Duncan's multiple range test.

phenomenon of compensating the poor leaf productivity of [T] in order to meet the demand from the sink. The cultivaral difference in leaf size enlarged in the grafts with $[\mathrm{K}]$ stock.

$\mathrm{Pn}, \mathrm{Gs}$ and Gm varied with stock cultivar as shown in Table 1. The average $\mathrm{Pn}$ in the grafts with $[\mathrm{K}]$ stock was $14.55 \mu \mathrm{mol} \mathrm{m} \mathrm{m}^{-2} \mathrm{~s}^{-1}$, showing a little higher than those $(13.56 \mu \mathrm{mol}$ 


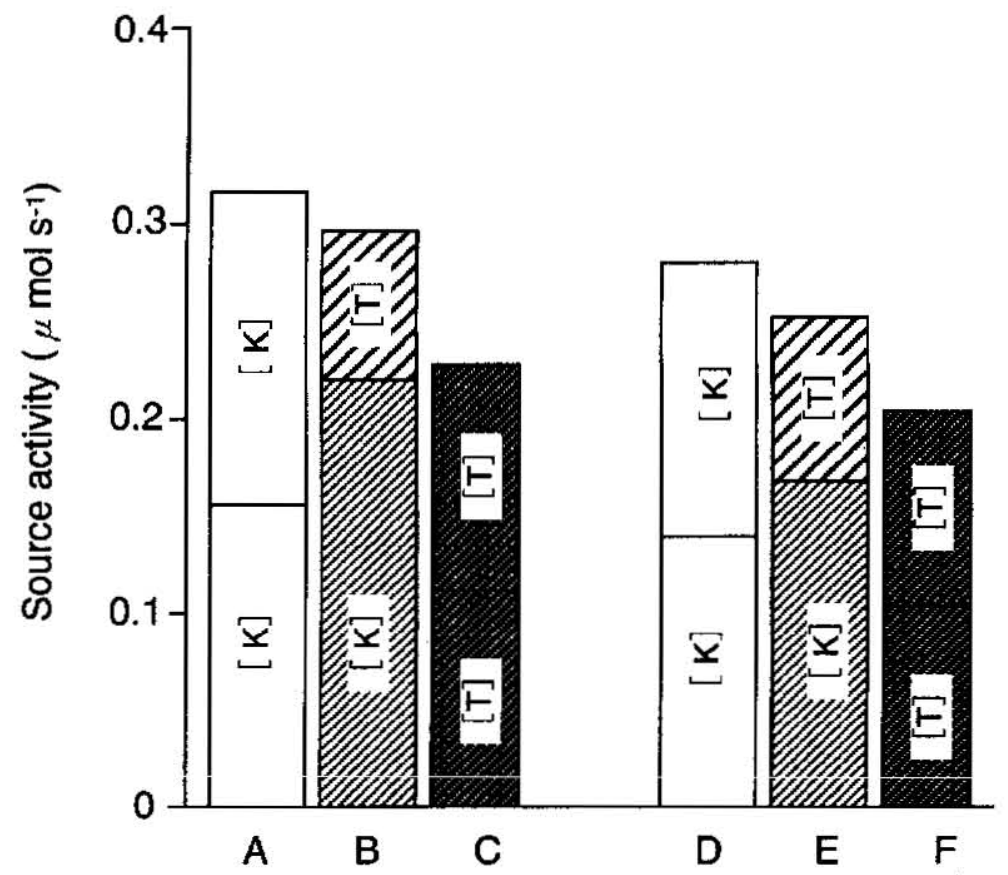

Fig. 4. Comparison of source activity (SOA) among the grafts with six scion stock combinations. $\mathrm{SOA}=$ photosynthetic rate $(\overline{\mathrm{P}} \mathrm{n}) \times$ leaf area.

$\mathrm{m}^{-2} \mathrm{~s}^{-1}$ ) in the grafts with [T] stock. Also both Gs and Gm were a slightly higher in the former. The cultivaral difference caused by stock cultivars was almost negligible, but it was clarified in the grafts with [K+T] leaves, in which Pn was 15.43 and $12.61 \mu \mathrm{mol} \mathrm{m}^{-2} \mathrm{~s}^{-1}$ in $[\mathrm{K}]$ and $[\mathrm{T}]$ leaves in the grafts with $[\mathrm{K}]$ stock, respectively, and also 14.31 and $11.92 \mu \mathrm{mol} \mathrm{m}^{-2} \mathrm{~s}^{-1}$ in the grafts with [T] stock, respectively. The competitive pressure was effective on leaf photosynthetic activity as well as leaf area produciion.

To compare the cultivaral difference in productivity of a leaf, SOA calculated as a product of $\mathrm{Pn} \times \mathrm{LA}$ are shown in Fig. 4. In the leaf combination of $[\mathrm{K}+\mathrm{T}]$, a significantly increased SOA was detected in $[\mathrm{K}]$ leaf and this phenomenon became more conspicuous in the grafts with $[\mathrm{K}]$ stock, in which the SOA of $[\mathrm{K}]$ showed over three times larger than that of [T]. These results suggest that the competitive condition in growth between grafted leaves is effective in clarifying their photosynthetic characteristics and cultivaral difference.

The relationship between SOA and the total weight of graft is shown in Fig. 5 . There was a highly significant linear relationship ( $\left.r=0.996^{* *}\right)$ between them, and this fact may prove that $\mathrm{SOA}$ is a valid indicator for source activity evaluation.

According to reports published until now, the activity of AGPase contained in amyloplasts is described as an important determinant of sink activity in sweet potato (Sowakino, 1976; Nakatani and Komeichi, 1992; Tsubone et al., 1997). AGPase activity in 


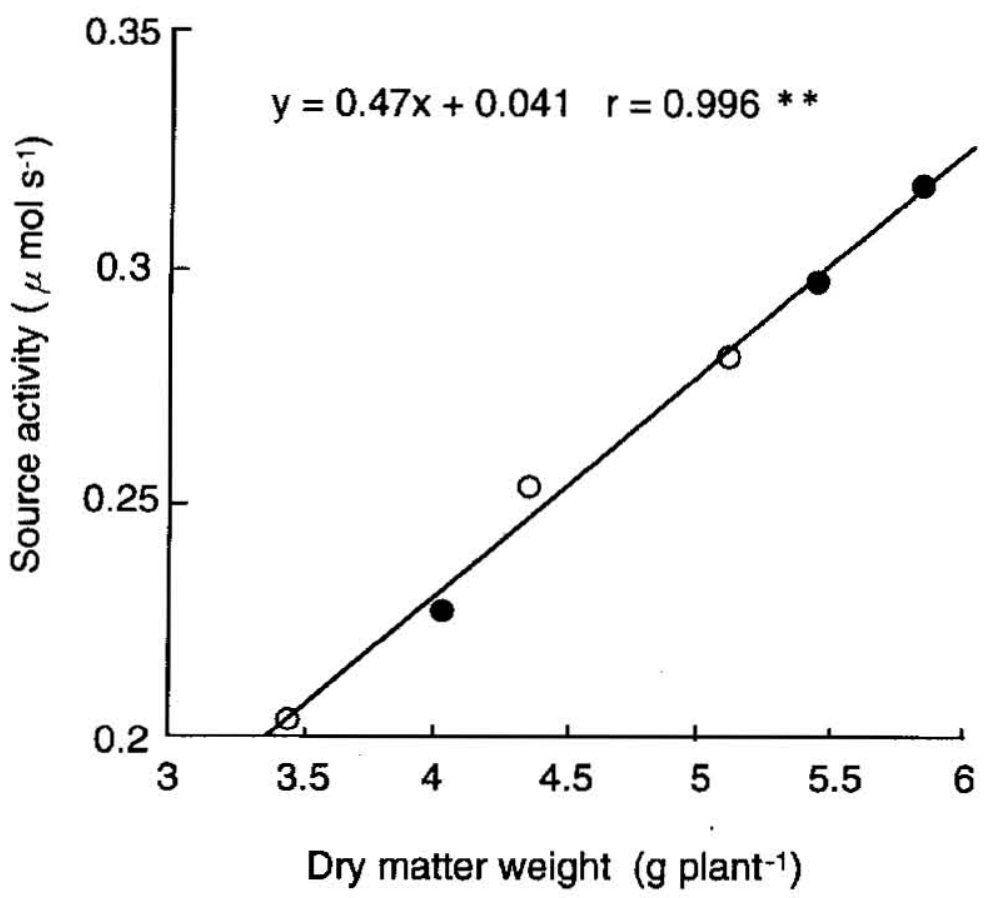

Fig. 5. The relationship between the dry matter weight of a whole plant and source activity (SOA). See Fig. 4. for SOA.

- Grafts with $[\mathrm{K}]$ stock; $\bigcirc$, grafts with [T] stock.

Table 2. Change in AGPase activity in roots with grafting combination.

\begin{tabular}{cc}
\hline Combination & $\begin{array}{c}\text { AGPase activity } \\
\text { (unit } \mathrm{gFW}^{-1} \text { ) }\end{array}$ \\
\hline A & 0.51 \\
B & 0.53 \\
C & 0.40 \\
\hline Average & 0.48 \\
\hline D & 0.17 \\
E & 0.16 \\
F & 0.00 \\
\hline Average & 0.11 \\
\hline
\end{tabular}

See Fig. 1 for the letters of A to $\mathbf{E}$. 
tuberous roots of the two-leaf grafts is shown in Table 2. The average activity of the grafts with [K] stock was several times higher than that, with [T] stock. It may be suggested that a high activity of AGPase is responsible for the high sink activity, and is recognized as one of the features in a high yield cultivar.

On the other hand, the activity of AGPase in the graft of $[\mathrm{T}+\mathrm{T}] /[\mathrm{T}]$ was negligible, and as a reason for this the stock of [T] is considered to have a poor activity as a sink organ. But the activity of AGPase greatly increased in the grafts of $[\mathrm{K}+\mathrm{T}] /[\mathrm{T}]$ and $[\mathrm{K}+$ $\mathrm{K}] /[\mathrm{T}]$. This suggests that the source activity or the amount of photosynthate transport to roots may play a role of trigger on enhancement of AGPase and sink activities, as reported by Tsubone et al. (1999).

From the results obtained here it may be concluded that the two-leaf graft is a useful test plant with a wide application from evaluating the cultivaral photosynthetic features to understanding the source-sink relationship from a biochemical view point.

\section{LITERATURES}

Hojo, Y. and C. Y. Park, 1971a Plant production in grafting plants between wild type and improved variety in Ipomoea. Bull. Nat. Inst. Agr. Sci. Japan, D22: 145-164

Hojo, Y, T. Murata and T. Yoshida 1971b The development of tuberous roots in grafting sweet potato plants, Ipomoea batatas Lam. Bull. Nat. Inst. Agr. Sci. Japan, D22; 165-191

Kubota, K., K. Iizuka and W. Agata 1993 Photosynthetic control factors in a single leaf of sweet potato, Ipomoea batatas Lam. 2. Sink-source relationship between photosynthesis and root weight production in single leaf grafts. Jpn. J. Crop Sci., 62: 248-256

Nakamura, Y., K. Yuki, S. -Y. Park and T. Ohya 1989 Carbohydrate metabolism in the developing endsperm of rice grains. Plant Cell Physiol., 30: 833-839

Nakatani, M., A. Oyanagi and Y. Watanabe 1988 Tuber sink potential in sweet potato (Ipomoea batatas Lam.). I. Development of tuber sink potential influencing the source activity. Jpn. J. Crop Sci., 57: $535-543$

Nakatani, M. and M. Komeichi 1988 Tuber sink potential in sweet potato (Ipomoea batatas Lam.). II Estimation of tuber sink potential of cultivars using single leaf grafts. Jpn. J. Crop Sci., 57: 544-552

Nakatani, M. and M. Komeichi 1992 Relationship hetween starch contert. dnd activity of starch synthase and ADP-glucose pyrophosphorylase in tuberous root of sweet potato. Jpn. J. Crop Sci, 61: $463-468$

Sowokino, J. R. 1976 Phyrophosphtorylases in Solanum tuberosum. I. Change in ADP-glucose and UDP-glucose pyrophosphorylase activities associated with starch biosynthesis during tuberization, maturation and storage of potatoes. Plant Physiol., 57: 63-68

Tsubone, M., F. Kubota and K. Saitou 1997 Effect of grafting on the activity of adenosine 5'-diphosphate glucose pyrophosphorylase and tuberous root production in swect potato (Ipomoea batatas Lam.). Jpn. J. Crop Sci., 66: $509-510$

Tsubone, M., F. Kubota, K. Saitou and M. Kadowaki 1998 Enhancement of tuberous root production and adenosine 5'-diphosphate glucose pyrophosphorylase (AGPase) activity in sweet potato, Ipomoea batatas Lam., by exogenous injection of sucrose solution. I. Agron. and Crop Sci., In Press

Yatomi, M., F. Kubota, K. Saitou and W. Agata 1996 Evalution of root sink ability of sweet potato (Ipomoea batatas Lam.) cultivars on the basis of enzymatic activity in the starch syrthesis pathway. J. Agron. and Crop Sci., 177: 17-23 